\title{
ANALYSIS OF AGRO-BIOTECHNOLOGICAL INNOVATIONS AND ADOPTION BEHAVIOUR OF PIG FARMERS IN OBUBRA LOCAL GOVERNMENT AREA, CROSS RIVER STATE, NIGERIA
}

\author{
I. B. ADINYA, E. E. ENUN, L. I. ENI AND G. EWONA
}

(Received 13 October 2011; Revision Accepted 27 April 2012)

\section{ABSTRACT}

This study analyzed agro-biotechnological innovations and adoption behaviour of pig farmers in Obubra Local Government Area of Cross River State. Data were collected from one hundred and twenty pig farmers from Obubra Local Government Area of Cross River State. A random sampling technique was employed in this study. Data collected were analyzed using descriptive statistics and Ordinary Least Square (OLS) regression, specifically, multiple regression analysis. The regression analysis, however, revealed that education, agricultural extension visit, effective agricultural communication strategy and adoption of improved technologies has positive influence on output of improved pig production and are significant at 5 percent level of significance. It was therefore recommended that the government should post more extension agents to the study area since agricultural extension visit / training of pig farmers on adoption of new technologies in pig production has positive influence on output of improved pig produced in Obubra Local Government Area of Cross River State.

\section{KEY WORDS: Adoption, New technologies, Pig Production, Agricultural Extension Visit}

\section{INTRODUCTION}

Adoption of agricultural research findings occurs if it meets the needs of the farmers or it is otherwise rejected (Roger and Shoe-maker, 1971; Ajayi and Madukwe, 2001; Ajayi and Oloruntoba, 2007). The problem of low productivity in pig production in Nigeria is cause by slow rate of adoption of new technologies by pig farmers, inefficient use of resources, poor funding of agricultural researches and poor extension delivery /inappropriate extension communication method used by extension agents. According to Adams (1982) adoption of new technology is not a sudden event, but a gradual process. Farmers do not accept new technologies immediately; they need to think things over before making a decision. There are four stages in adoption process, namely: knowledge, persuasion, decision and confirmation. Adopters of new technologies has been subdivided into four categories on the basis of the relative time they take to adopt new technologies, namely: innovators, early adopters, early majority, late majority and laggards.

Nigeria is reported to rank second in pig production in Africa. Nigeria produces 5.1 million out of total world average of $930,318,700$ and pig meat contributes about $4.5 \%$ of meat consumption in Nigeria (Food and Agriculture Organization, 2002; Istifanus et al, 2010). The demand for pork meat has exceeded the supply and this has resulted in increase in price of pork meat in the markets and has put pig farmers in such a position where they need information on scientific breakthrough to meet up the demand for pork meat (Adinya et al, 2008). The rapid population growth rate without corresponding increase in livestock production has resulted to protein supply deficit (Food and Agriculture Organization, 2002; Istifanus et al, 2010; Adinya 2008). In-spite of the efforts of Agricultural Development Programmes (ADPs) in technologies transfer to farmers but food production continue to dwindle each year. This deficit in food production has been attributed to a number of factors among which include non-adoption of new technologies by farmers, lack of experience extension agents, inadequate funding of agricultural researches, poor/wrong policies formulation and inadequate input supply (Roger and Shoe-maker, 1971; Ajayi and Madukwe, 2001; Ajayi and Oloruntoba, 2007).

Protein deficiency problem in Nigeria can be arrested through agricultural research/agrobiotechnology, effective/efficient agricultural extension services, efficient resource use and adoption of new technologies in pig production (Isek, 2007; Adinya et al, 2008).

Some pig farmers in the rural areas are illiterates, therefore cannot read or write, they need agricultural extension agents through which such information from research station(s) will be interpreted to them. Agricultural extension service is a necessary

I. B. Adinya, Department of Agricultural Economics and Extension, Cross River University of Technology (CRUTECH), Obubra, Cross River State, Nigeria.

E. E. Enun, Department of Agricultural Economics and Extension, Cross River University of Technology (CRUTECH), Obubra, Cross River State, Nigeria.

L. I. Eni, Department of Agric. Education, Cross River University of Technology (CRUTECH), Obubra, Cross River State, Nigeria.

G. Ewona, Department of Agric. Education, Cross River University of Technology (CRUTECH), Obubra, Cross River State, Nigeria. 
prerequisite to widespread and sustained agricultural development. It is not possible, even in highly developed countries, to encourage farmers to adopt new technology or more efficient production practices based on continuously advancing research results and new agricultural techniques to farmers, some one must teach farmers how these practices should be used and adopted under their own individual farming and resource availability. Thus agricultural extension service is needed to teach farmers how to adopt improved pig production practices. Efficient food supply in any country depends to a large extent on the level of agricultural production, research and agricultural extension services of such nation (Adinya et al 2006; Arshad et al, 2007; Adeshinwa et al, 2007; Barao. 1992). Agricultural extension service is a unique service that provides nonformal education and improved information services that help in increasing small and large-scale farmers' productivity and ensure food security. Arshad et al (2007) revealed that agricultural extension services is one of the means available to promote the exchange of information that can be converted into functional knowledge, which is instrumental in helping to promote productivity and generate income to alleviate poverty. Agricultural extension services seeks to impart knowledge, vocational skills and stimulate farmers' adoption, application and continuous use of the new farm innovations and technologies in improving the farming practices and standard of living (Onu et al, 2003; Adesope and Agumagu, 2003). Adedoyin (2004) noted that in order to solve the problems of farmers, it is important for input supply agencies to open up more distribution centers in rural areas and increase the stock of goods meant for sale to farmers and at reduced prices.

\section{Theoretical framework on adoption behaviour of pig farmers}

Roger and Shoe-maker, 1971; Ajayi and Madukwe, 2001; Ajayi and Oloruntoba (2007)revealed that access to information about an innovation is the key factor determining adoption decision. Imoke (2009) suggested that the perceived attributes of innovation(s) determine adoption behaviour. Farmers have subjective preferences for technology characteristics and these could play a major role in technology adoption (Roger and Shoe-maker, 1971; Ajayi and Madukwe, 2001; Ajayi and Oloruntoba, 2007). The adoption or rejection of technologies by farmers may be based upon farmer's perception of the appropriateness or in- appropriateness of the characteristics of the practices under consideration.

Several studies of adoption behaviour (Udokang, 2011; Ajayi and Oloruntoba, 2007; Adeshinwa et al, 2007; Barao. 1992) showed that the dependent variables are constrained to lie between 0 and 1 and the models used are exponential functions. Univariate and multi-variate logit and probit models are commonly used and their modifications have been used extensively to study adoption behaviour of farmers. According to Udokang, 2011; Ajayi and Oloruntoba, 2007; Adeshinwa et al, 2007; Barao(1992), farmers adoption decision are reasoned to be based upon utility maximization.

Ime (2003) revealed that in Nigeria, series of extension strategies have been used to promote the transfer of new technologies and farming practices, but have been hindered mostly by poor monitoring system; poor research communication system, poor financial allocation to various extension agencies. All these have created a wide gap in technology development and transfer in all aspect of agriculture to farmers. Ike (2003) revealed that there is a wide gap between what research findings have shown to be possible and feasible on the one hand, what actually obtains on the other. He further state that, irrespective of the potential and promise of any agricultural research findings, the full potential cannot be realized until it has been brought to the knowledge of the intended beneficiaries(farmers). Ike (2003) revealed that many factors affected communicating of agricultural innovations to farmers, these include; inappropriate communication strategies are used by extension agents to reach farmers and many research institutes have not fashioned out effective means of disseminating their improved research results to farmers

Cross River Agricultural Development Programme (CRADP) set goals for the rural extension workers, aimed at increasing the productivity and income of farmers in their areas of jurisdiction. To achieve this laudable objective, the extension aim of CRADP has an organizational structure, which permits the flow of information from the Chief Agricultural Extension Officer down to the baseline staff describe as extension agents (EAs) or village extension worker who teaches improved production technologies, he also brings back to the research station information on actual farm production condition, impact of agricultural extension service on the farmers and farmers' reaction to recommended practices (Benor and Baxter,1984).

It is hoped that, the performance of pig farmers would improve and this will result in increased pig production.

The main objective of this study is to analyzed agro-biotechnological innovations and adoption behaviour of pig farmers in Obubra Local Government Area of Cross River State. Specifically, it sought to:

i. Determine the socio-economic characteristics of small-scale pig farmers in the study area;

ii. Investigate the adoption of recommended technologies by pig farmers in the area under study, and

iii. Identify the factors that militate against increase pig production and make policy recommendations.

\section{METHODOLOGY}

Study Area: The area of study is Obubra Local Government Area of Cross River State. Obubra lies on latitude $6^{\circ} 05^{\prime} \mathrm{N}$ and longitude $8^{\circ} 20^{\prime} \mathrm{E}$. Obubra is bounded on the East by lkom, North by Yala, and in the South by Yakurr Local Government Areas of Cross River State, while in the West by Afikpo Local Government Area of Ebonyi State as shown in the map attached (CRADP, 1990 In: Adinya et al, 2007). 
Obubra lies along the humid coastal region and is within the Ikom Agricultural Zone of Cross River State. The topography is fairly flat with a good drainage system. The soil is predominantly sandy loam. The area has an annual rainfall distribution, which ranges from $2,500 \mathrm{~mm}$ to $3,000 \mathrm{~mm}$ with an annual temperature of 25$27^{0} \mathrm{c}$ (Adinya et al, 2007). Obubra is situated in the rainforest belt, which promotes the growth of crops such as oil palm, oranges, plantain, banana and guava, rice, yam, cassava, potato, coco yam, maize and vegetables. Fishing and keeping of animals like goats, sheep and poultry birds are among the area of interest of the people. Apart from farming, the people are also engaged in agro-based activities, while a good number are involved in civil service, marketing of agricultural products (trading) and other forms of non-farming activities or business (Adinya et al, 2007).

\section{Sampling technique and sample size}

The Cross River Agricultural Development Programme (CRADP) covers an area of about 22,342.176 square kilometers (Quarterly Newsletter of the Ministry of Local Government Affairs, Cross River State, 2006). There are three agricultural zones in the state, each headed by zonal manager as follows: Calabar Zone comprises of Calabar South, Calabar Municipal, Bakassi, Akpabuyo, Odukpani, Akamkpa and Biase Local Government Areas.

Ikom Zone comprises of Boki, Etung, Ikom, Obubra, Yakurr and Abi Local Government Areas.

Ogoja Zone comprises of Bekwarra, Yala,

Ogoja, Obudu and Obanliku Local Government Areas.
Random sampling technique was employed in this study. Out of the three Agricultural Zones of Cross River State, one zone (lkom Agricultural Zone) was purposively selected.

There are seven cells in Obubra Local Government Area. Three cells were randomly selected from seven cells in Obubra Local Government Area. Four villages were randomly selected from each of three cells to give a total of twelve (12) villages. This was followed by a random selection of 10 respondents from each village to give a total of 40 pig farmers from each cell. In all, 120 pig farmers were used for the study. Besides, three agricultural extension agents representing one from each cell were interviewed

\section{Data type and collection}

Both primary and secondary sources of data were used. The secondary sources of data include Annual Reports, book census data, journals, statistical documents, whereas the primary data source were drawn from field survey via structured questionnaires. The researchers developed two sets of questionnaires with one set for the pig farmers and the other set for the extension agents in-charge of the pig farmers. The researchers visited the villages to administer the questionnaires to selected farm families as a pilot survey to pretest the instrument. Thereafter, the instrument was corrected to override the problem of ambiguity and misperception and ensure that the instruments are accurate. Thus its validity is guaranteed. 
Analytical Framework

The method of data analysis employed in this paper is the Ordinary Least Square (OLS) regression. Specifically, multiple regression analysis was used with the aid of Special Package for Social Sciences (SPSS) analytical software package (SPSS 17.0).

\section{Model specification}

The model for the study with respect to pig output and the recommended pig-based technologies have been specified. Precisely, the hypothesized structural relationship for the pig -based technologies was given as follows:

$Y=b o+b_{1} X_{1}+b_{2} X_{2}+b_{3} X_{3}+b_{4} X_{4}+b_{5} X_{5}+e$...equation (1)

where $\hat{Y}=$ Output of pig (kg/ha)

$\mathrm{X}_{1}=$ Respondents educational level of the respondents (First

School Leaving Certificate $=1$, JSSC/SSC $=2$ Tertiary

Institutions $=3$, no formal education $=4)\left(b_{1}>0\right)$

$\mathrm{X}_{2}=$ Farm size $(\mathrm{ha})\left(\mathrm{b}_{2}>0\right)$

$\mathrm{X}_{3}=$ Labour (man-days) $\left(\mathrm{b}_{3}>0\right)$

$\mathrm{X}_{4}=$ Frequency of Agricultural extension visit (once $=1$;

Twice = 2; thrice=3; four times=4; every day=5; none $=6)\left(b_{.4}>0\right)$

$\mathrm{X}_{5}=$ Adoption of improved pig technologies (improved breed of

Pig = 1; supplementary feed=2; de-worm of pig=3; cleaning of pens,

Vaccination $=4$; all of the above $=5)\left(b_{5}>0\right)$

$\mathrm{e}_{1}=$ Error term (mainly to capture the effects of exogenous and endogenous variables not included in the model).

$\mathrm{b}=$ Regression constant

$\mathrm{X}_{1} \mathrm{X}_{5}=$ Regression coefficient of respective variables. It is however, expected that the parameters $\left(\mathrm{X}_{1}\right.$ $\mathrm{X}_{5}$ ) would be positive on a priori grounds.

\section{Estimation techniques}

The study adopts the Ordinary Least Square (OLS) estimation procedure. On the basis of the specified model (equation 1).

Four function forms of equation were estimated, these were Linear, double-log(Cobb-Douglas production function), semi-log and exponential (see equation 2). The lead equation was selected on the basis of three criteria, namely econometric, statistics and theory. In other words selection of lead equation was based on the highest value of the coefficient of determination $\left(\mathrm{R}^{2}\right)$.Statistical significant of the regression coefficient, the F- Statistics, Durbin Watson statistics (Kmenta, 1971; Koutsoyiannis, 1977 and Awoke, 2001).

The functional forms fitted are specified below:

(i) Linear form:

$$
Y=b o+b_{1} X_{1}+b_{2} X_{2}+b_{3} X_{3}+b_{4} X_{4}+b_{5} X_{5}++ \text { e...equation (2) }
$$

(ii.) Cobb-Douglas Production Function (double log)

$\log Y=b o+b_{1} \operatorname{Ln} X_{1}+b_{2} L n X_{2}+b_{3} L n X_{3}+b_{4} L n X_{4}+b_{5} \operatorname{Ln} X_{5}+e . .$. equation (3)

(iii.) Semi-Logarithm form:

$Y=b o+b_{1} L n X_{1}+b_{2} \operatorname{Ln} X_{2}+b_{3} \operatorname{Ln} X_{3}+b_{4} L n X_{4}+b_{5} \operatorname{Ln} X_{5}+e \ldots$ equation (4)

(iv.) Exponential form:

In $Y=b o+b_{1} L n X_{1}+b_{2} \operatorname{Ln} X_{2}+b_{3} L n X_{3}+b_{4} L n X_{4}+b_{5} L n X_{5}+e \ldots$ equation (5) 
RESULTS AND DISCUSSION

Table 1: Distribution of respondents according to socio-economic characteristics of pig farmers in Obubra Local Govern Area, Cross River State

\begin{tabular}{llllll}
\hline $\begin{array}{l}\text { Educational } \\
\text { Attainment }\end{array}$ & Osopongll & Ochon & Ofumbongha & Frequency & $\begin{array}{l}\text { Percentage } \\
(\%)\end{array}$ \\
\hline FSLC & 4 & 10 & 14 & 28 & 23.33 \\
JSSC/SSSC & 21 & 13 & 13 & 47 & 39.17 \\
Tertiary Institution & 15 & 14 & 12 & 41 & 34.17
\end{tabular}

No formal education

\begin{tabular}{|c|c|c|c|c|c|}
\hline & - & 3 & 1 & 4 & 3.33 \\
\hline Total & 40 & 40 & 40 & 120 & 100 \\
\hline $\begin{array}{l}\text { Farm size } \\
\text { (hectares) }\end{array}$ & Osopongll & Ochon & Ofumbongha & Frequency & $\begin{array}{l}\text { Percentage } \\
(\%)\end{array}$ \\
\hline $0.1-2$ & 34 & 37 & 27 & 98 & 81.67 \\
\hline $3-4$ & 6 & 3 & 13 & 22 & 18.37 \\
\hline $5-6$ & - & - & - & - & - \\
\hline 7-8 & - & - & - & - & - \\
\hline 9 ha and above & - & - & - & - & - \\
\hline Total & 40 & 40 & 40 & 120 & 100 \\
\hline $\begin{array}{l}\text { Labour } \\
\text { (man-days) }\end{array}$ & Osopongll & Ochon & Ofumbongha & Frequency & $\begin{array}{l}\text { Percentage } \\
(\%)\end{array}$ \\
\hline 1 & 9 & 5 & 4 & 18 & 15.00 \\
\hline 2 & 12 & 10 & 10 & 32 & 26.67 \\
\hline 3 & 8 & 12 & 9 & 29 & 24.17 \\
\hline 4 & 4 & 9 & 7 & 20 & 16.67 \\
\hline 5 & 5 & 1 & 6 & 12 & 10.00 \\
\hline 6 man-days and above & 2 & 3 & 4 & 9 & 7.50 \\
\hline Total & 40 & 40 & 40 & 120 & 100 \\
\hline $\begin{array}{l}\text { Agricultural Extension } \\
\text { visits }\end{array}$ & Osopongll & Ochon & Ofumbongha & Frequency & $\begin{array}{l}\text { Percentage } \\
(\%)\end{array}$ \\
\hline Once & 10 & 19 & 10 & 39 & 32.50 \\
\hline Twice & 1 & 5 & 13 & 19 & 15.83 \\
\hline Thrice & 1 & 5 & 13 & 19 & 15.83 \\
\hline Four times & - & - & - & - & - \\
\hline Every day & - & - & - & - & - \\
\hline None & 29 & 16 & 17 & 62 & 51.67 \\
\hline Total & 40 & 40 & 40 & 120 & 100 \\
\hline $\begin{array}{l}\text { Adoption of improved } \\
\text { technologies }\end{array}$ & Osopongll & Ochon & Ofumbongha & Frequency & $\begin{array}{l}\text { Percentage } \\
(\%)\end{array}$ \\
\hline Improved breed of pig & 11 & 10 & 7 & 28 & 23.33 \\
\hline $\begin{array}{l}\text { Improved } \\
\text { management } \\
\text { system }\end{array}$ & 8 & 10 & 8 & 26 & 21.67 \\
\hline $\begin{array}{l}\text { Provision of } \\
\text { supplementary feed }\end{array}$ & 1 & 6 & 4 & 20 & 16.67 \\
\hline $\begin{array}{l}\text { Provision of } \\
\text { vaccines/drugs }\end{array}$ & 10 & 8 & 15 & 24 & 20.00 \\
\hline All of the above & 10 & 6 & 6 & 22 & 18.33 \\
\hline Total & 40 & 40 & 40 & 120 & 100 \\
\hline
\end{tabular}

Source: Field survey, 2012

Analysis of table 1 revealed that $39.17 \%$ of the respondents had Junior Secondary School Certificate (JSSC)/Senior Secondary School Certificate(SSSC). However, $34.17 \%$ of the respondents disclosed that they had First School Leaving Certificate (FSLC). Only 3.33\% of the respondents never had formal education. Table 1, also revealed that $24.17 \%$ of the respondents farm sizes were between $0.1-2$ hectares. While $18.37 \%$ of them had farm sizes ranging from 3-4 hectares. Further analysis of Table revealed that $24.17 \%$ of the respondents spent 3 man-days. Whereas, $10 \%$ of them spent 5 man-days. Only $7.50 \%$ of the respondents spent 6 man-days and above. Table 1, revealed that $32.50 \%$ of the respondents disclosed that agricultural extension 
agents visited them once. Whereas 15.83 of them revealed that agricultural extension agents visited them twice. While $51.67 \%$ of the respondents disclosed that agricultural extension agents did not visit them. Finally, Table 1 revealed that $2.33 \%$ of the respondents revealed that they adopted improved cassava stems. Whereas $21.67 \%, 16.67 \%$ and $20 \%$ of the respondents revealed that they adopted improved pig management system, provision of supplementary feed and provision of vaccines/drugs respectively.

Table 2: Distribution of respondents according to income structure

\begin{tabular}{|c|c|c|c|c|c|}
\hline $\begin{array}{l}\text { Income } \\
\text { naira(N) }\end{array}$ & Osopongll & Ochon & Ofumbongha & Frequency & $\begin{array}{l}\text { Percentage } \\
(\%)\end{array}$ \\
\hline $\begin{array}{l}100,000.00- \\
200,000.00\end{array}$ & & & & & \\
\hline $\begin{array}{l}200,000.00 \\
110, \quad 000.00-\end{array}$ & 15 & 4 & 1 & 20 & 16.67 \\
\hline $\begin{array}{l}210,000.00 \\
220, \quad 000.00-\end{array}$ & 12 & 10 & 9 & 31 & 25.83 \\
\hline $\begin{array}{l}310,000.00 \\
320,000.00\end{array}$ & 1 & 7 & 12 & 20 & 16.67 \\
\hline $\begin{array}{l}\text { above } \\
\text { Total }\end{array}$ & $\begin{array}{l}12 \\
40\end{array}$ & $\begin{array}{l}19 \\
40\end{array}$ & $\begin{array}{l}18 \\
40\end{array}$ & $\begin{array}{l}49 \\
120\end{array}$ & $\begin{array}{l}40.83 \\
100\end{array}$ \\
\hline
\end{tabular}

Source: Field survey, 2012

From Table 2, $40.83 \%$ of respondents earned income between $N 320,000.00$ and above, whereas $16.67 \%$ of them earned farm income between N220, 000.00A310,000.00 annually. While, $25.83 \%$ of them earned
N11, 000.00- N20,000.00 annually. Only $16.67 \%$ of the respondents earned farm income between $\mathrm{N100,000.00-}$ N110,000.00 annually.

Table 3: Summary of estimates of the relationship between pig output and pig-based technologies in the study area

\begin{tabular}{|c|c|c|c|c|}
\hline Parameter & Linear & Semi-log & Double-log & Exponential \\
\hline constant & $\begin{array}{l}-2.253 \\
(1.498)\end{array}$ & $\begin{array}{l}-3.754 \\
(5.058)\end{array}$ & $\begin{array}{l}-15313 \\
(0.710)\end{array}$ & $\begin{array}{l}-1.761 \\
(6.203)\end{array}$ \\
\hline Educational level & $\begin{array}{l}0.174 \\
(0.212)\end{array}$ & $\begin{array}{l}0.579 \\
(1.008)\end{array}$ & $\begin{array}{l}9.688 \\
(-0.142)\end{array}$ & $\begin{array}{l}0.549 \\
(0.765)\end{array}$ \\
\hline Farm size & $\begin{array}{l}0.130 \\
(0.117)\end{array}$ & $\begin{array}{l}1.053 \\
(0.912)\end{array}$ & $\begin{array}{l}0.251 \\
(0.128)\end{array}$ & $\begin{array}{l}0.365 \\
(0.316)\end{array}$ \\
\hline Labour & $\begin{array}{l}1.237 \\
(0.163)\end{array}$ & $\begin{array}{l}7.249 \\
(1.182)\end{array}$ & $\begin{array}{l}-0.941^{* * *} \\
(0.166)\end{array}$ & $\begin{array}{l}1.653 \\
(0.175)\end{array}$ \\
\hline $\begin{array}{l}\text { Agricultural } \\
\text { Extension visits }\end{array}$ & $\begin{array}{l}1.293 \\
(0.0492)\end{array}$ & $\begin{array}{l}4.015 \\
(1681)\end{array}$ & $0.996^{* * *}$ & $\begin{array}{l}1.438 \\
(0268)\end{array}$ \\
\hline Adoption & $\begin{array}{l}(0.0492) \\
0.246\end{array}$ & 0.995 & $0.165^{\star \star *}$ & 0.998 \\
\hline $\begin{array}{l}\text { improved pig } \\
\text { production } \\
\text { technologies } \\
\text { Diaanostics }\end{array}$ & $(0.374)$ & (1.306) & $(0.183)$ & (1.402) \\
\hline & 0.600 & 0.552 & 0.612 & 0.613 \\
\hline Adjusted $R^{2}$ & 0.565 & 0.510 & 0576 & 0.571 \\
\hline F--ratio & 16.427 & 13.393 & 17.163 & 16.151 \\
\hline Durbin watson & 1.998 & 1.929 & 1.99 & 1.989 \\
\hline
\end{tabular}

Source: Authors' Survey Results (2012)

${ }^{\star * *}$ significant at $1 \%$

Value in parentheses are standard errors

Judging from the values of the $\mathbf{R}^{2}$ in the analysis in Table 3 reveals that double log equation is a good one compared to all other functional forms (Linear, Semi-log and Exponential). Double-log (Cobb-Douglas production function) is the lead equation because it has the highest $\mathbf{R}^{2}$

Value (0.613) and meeting other econometric criteria. The choice of double-log production function among the function tried Linear, Semi-log, Double$\log$ (Cobb-Douglas) and Exponential). Was because it had the best fit to data as reflected by $\mathbf{R}^{2}$ While Durblin Watson (DW) statistic was 1.99. The DW value of 1.99 was within the specified range of between 0 and 2 , indicating positive autocorrelation. The F-value for the functions are also significant at 1 per cent indicating that there is a significant linear relationship between the independent percent indicating that there is a significant linear relationship between the independent variables taken together and the output of pig produced in Obubra Local Government Area of Cross River State. 
Further analysis of Table 3 , revealed that labour, farm size, education, agricultural extension visit and adoption of improved technology has positive influence on output of pig production and it is significant at one per cent level of significance. The F-value of 17.163 indicates the overall significant of the model at the one per cent level. Karlirajan (1981) and Fujimoto (1988) reported similar results for labour in the aggregate; while Arshad et al (2007) and Agumagu (2000) reported similar results for agricultural extension visit and Istifanus et al (2010) reported similar results adoption of improved technology.

Table 4: Constraints against pig production in Obubra L.G.A..C.R.S Nigeria

\section{Constraints} Total Frequency Percentage Mean S.D. Coefficient of Variation

High cost of vaccines

High transport cost of feed

Lack of roads maintenance/bad roads

Lack of price information

in adequate finance

Inaccessibility of formal credit source

because lack of collaterals

Inaccessibility of formal credit source because high interest rate

\section{8}

12

10

11

17

14

11

Inaccessibility of formal credit source

because of short repayment period

Inappropriate extension delivery strategies

Non-adoption of new technologies

Total 120

$\begin{array}{llll}15 & 12 & 4 & 33.33 \\ 10 & 12 & 4 & 33.33 \\ 8.33 & 12 & 4 & 33.33 \\ 9.17 & 12 & 4 & 33.33 \\ 14.17 & 12 & 4 & 33.33 \\ 11.67 & 12 & 4 & 33.33\end{array}$

9.17

12

4

33.33

6.66

9.17

6.66

12

12

12

4

33.33

33.33

33.33

Source: Field survey, 2012.

The study revealed that several constraints militating against pig production in Obubra Local Government Area of Cross River State, Nigeria. These constraints are presented on Table 4. From the table, the constrain of high cost of vaccines, inadequate finance and non-adoption of new technologies occupied $15 \%, .14 .17 \%$ and $6.66 \%$ respectively. The result of the study agrees with the findings of Istifanus et al, 2010; Okoli et al, (2009) revealed that some constraints militating against the efficient pig production. In addition, it was observed that the standard deviation of the factors from mean of 12 was 4 . Statistically, these factors were observed to have a coefficient of variation of 33.33.

\section{CONCLUSIONS AND POLICY RECOMMENDATIONS}

Agricultural extension imparts knowledge, vocational skills and stimulate farmers' adoption, application and continuous use of the new farm innovations and technologies in improving the farming practices and standard of living. Agricultural extension services is a prerequisite for widespread and sustained agricultural development. This study has shown revealed that $39.17 \%$ of the respondents had Junior Secondary School Certificate(JSSC)/Senior Secondary School Certificate(SSSC). However, $34.17 \%$ of the respondents disclosed that they had First School Leaving Certificate (FSLC). Only 3.33\% of the respondents never had formal education. $32.50 \%$ of respondents spent 1-5 years in pig farming in the study area. Those that spent $6-10$ years had $29.17 \%$, while those that spent $11-15$ years had $15.00 \%$. Similarly, those that spent $16-20$ years had $23.3 \%$. It was, therefore, recommended that the government should post more extension agents to the study area since agricultural extension visit/training of pig farmers on adoption of new technologies in pig production has positive influence on output of pig produced in the study area.

\section{REFERENCES}

Adams, M. E., 1982. Agricultural Extension in Developing Countries. Longman Group Limited, United Kingdom. 1-7.

Adedoyin, S., 2004. Plentiful Agricultural Resources but Limited androgogical transmission. 33 Inaugural Lecture Olabisi Onabajo University, Ago Iwoye. P51

Adeshinwa, A. O. K., Ajala M. K., and Yakubu, L., 2007. Determinants of herd size of pigs in Southern Kaduna Area of Kaduna State,Nigeria. Tropical and Sub - Tropical". Agro-ecosystems, (7): 123126.

Adesope, O. M. and Agumagu, A. C., 2003. Socioeconomic factors as correlates of job stress among Extension Agents Journal of Extension System. 19, (1): 54-57.

Adinya I. B., Ajayi S. and Idiege, D. A., 2006. Economic Analysis of Cassava Production in Akwa lbom State. Journal of Agriculture, Forestry and Social Sciences 4, (2): (2006).

Adinya I. B., Enya, V. E. and Kuye O. O., 2007. Structure of Ofatura Goat Market Obubra Local 
Government Area, Cross River State, Nigeria. Global Journal of Agricultural Sciences. 6, (1): 55-59. Ajol (UK):http://www.inasp.Info/ajol

Adinya I. B., Ibom, L. A., Ayuk, E. A., Agiopu, B. F., Umoh, E. E. and Umeh G. N., 2008. Analysis of Selected Variables Affecting Small-scale Pig Production in Cross River State, Nigeria". Wilolud Online Journals, 2008,Continental Journal of Agricultural Economics 2, 52-57.

Agumagu, A. C., 2000. Poverty Alleviation in Nigeria; Can Agricultural Extension Help? Paper Presented at $6^{\text {th }}$ Annual Conference of Agricultural Extension Society of Nigeria (AESON)! $0-13^{\text {th }}$ April, 2000, University of Ibadan, Nigeria. PP11.

Ajayi, A. R. and Madukwe, M. C., 2001. The Potential Role of Agricultural Extension in AgroBiotechnological Innovation Generation and Adoption in developing Countries: A case study of Nigeria. Journal of the Science of Agriculture, Food Technology and Environment 1, (1):39-40.

Ajayi, M. T. and Oloruntola, A., 2007. Assessment of factors affecting farmers' adoption and utilization of major agricultural technologies developed by International Institute of Tropical Agriculture. Journal of Agriculture, Forestry and the Social Sciences. 5, (1): 20-28.

Arshad, F., Mohammed, I. and Shaukat, H. S., 2007. Impact of devolution on Agricultural Extension System in North West Frontier Province Pakistan. Global Approaches to Extension Practices (GEAP) 3, (1): 30-35.

Awoke, M. U., 2001. Econometrics: Theory and Application. WillyRose and Appleasaced Publishing Company Abakaliki Nigeria. 1-16.

Benor, D and Baxter, M., 1984. Main features of training and visit system of Agricultural Extension "The World Bank, Washington D.C. 90-120.

Barao, S. M., 1992. Behavioral aspect of technology adoption. Journal of Extension, 30, (2): 1-10.

Cross River Agricultural Development Project., 1990. Report on Wetlands of Cross River State, Nigeria. 115.

Food and Agricultural Organization 2002., World pig population report, December, 2002. 1-10.

Fujimoto, A., 1988. "The Economics of Land Tenure and Rice Production in a Double Cropping Village in Southern Thailand" American Journal of Agricultural Economics 26, (3): 190-210.

Istifanus, I. D., Adebambo, D. A and Adesehinwa, A. O., 2010. "Status of pig production and marketing in Nigeria: An overview of current practices, problems and prospects". A paper presented at $1^{\text {st }}$ Nigerian
Internal pig summit held at Institute of Agricultural Research and Training, Moor Plantation, Ibadan, $22-25^{\text {th }}$ November, 2010. 116.

Ike, N., 2003. Agricultural Communication Principles and Practicies. Published by Lamb House Publisher, P. O. Box 700. Umuahia, Nigeria. 1-30.

Ime, J. C., 2003. "Farmers' Perception of the Unified Agricultural Extension System of Akwa lbom Agricultural Development Programme (AKADEP)", An unpublished M.Sc. Dissertation, University of Uyo, Akwa Ibom State.

Imoke, P. A., 2009. The Determinants of rate of adoption of improved cassava varieties by farmers in Obubra Local Government Area of Cross River State, Nigeria. Unpublished B. Agric. Project, Department of Agricultural Economics and Extension, CRUTECH, Obubra Campus, 1'-22.

Isek, P. I., 2007. Effect of selected Agricultural Extension variables on cassava production in Obubra Local Government Area, Cross River State, Nigeria. Unpublished B. Agric. Project, Department of Agricultural Economics and Extension, CRUTECH, Obubra Campus, 1-40.

Kalirajan, K., 1981. "An Econometric Analysis of Yield of Variability in Paddy Production". Canadian Journal of Agricultural Economics. 25, (8): 286291.

Kmenta, J., 1971. Elements of Econometrics, Macmillan Co. Inc. New York 1-18.

Koutsoyiannis, A., 1977. Theory of Econometrics. Published by Macmillan 1- 667

Okoli, I. C., Ogechi, R., Alaoma, M. N., Opara, M. C., Uchegbu, M. C., Ezeokeke, C. T. E., Duruna, C. S., Nnadi, F. N., Iheukwumere, F. C. and Okeudo, N. J., 2009. "Socio-economic characteristics of smallholders farmers and the effect of their feeding practices on the performance of pigs in Imo State, Nigeria". Report and Opinion (4): 5965.

Onu, D. O., Adesope, O. M and Udokang, D. O., 2003. Evaluation of Work-Related Stress Characteristics Among Agricultural Extension Agents. Journal of Agriculture, Forestry and the Social Sciences. 1, (1): 19.

Quarterly New Letter of The Ministry of Local Government Affairs Cross River State (2006). 48.

Rogers, E. M and Shoemaker, F. F., 1971. Communication of Innovations. Second Edition The Free Press, New York.1-15.

Udokang, E. J., 2011. Analysis of the performance of adoption methods among cassava growers in 
Obubra Local Government Area, Cross River

State, Nigeria. Unpublished B. Agric. Project,

Department of Agricultural Economics and

Extension, CRUTECH, Obubra Campus, 1-26. 